\title{
Rat Kidney Thromboxane Receptor: Molecular Cloning, Signal Transduction, and Intrarenal Expression Localization
}

Takaaki Abe, Kazuhisa Takeuchi, Nobuyuki Takahashi, Eikatsu Tsutsumi, Yoshiyuki Taniyama, and Keishi Abe

The Second Department of Internal Medicine, Tohoku University School of Medicine, Sendai 980-77, Japan

\begin{abstract}
Thromboxane ( TX) plays important roles in control of renal hemodynamics and water and electrolyte metabolism, and is involved in the pathophysiology of many renal diseases. The aim of the present study is to isolate a rat kidney cDNA encoding functional TX receptor, and to reveal its intrarenal expression localization. A clone (rTXR2) was isolated from a rat kidney cDNA library by a homology screening approach. rTXR2 was shown to encode the amino acid sequence containing seven transmembrane spanning domains representing rat ( $r)$ TX receptor. The membrane from COS-7 cells transiently transfected with rTXR2 cDNA was shown to be specifically bound by a thromboxane receptor antagonist, SQ29548. Either in Xenopus oocyte expression or in transfected COS-7 cells, rTX receptor was shown to be linked with $\mathrm{Ca}^{2+}$ messenger system. TX receptor-mediated increase in cytosolic $\mathrm{Ca}^{2+}$ was also observed in cultured glomerular mesangial cells. In situ hybridization showed that rTX receptor mRNA was detected in renal glomeruli, smooth muscle cells in renal arterioles, and transitional cell epithelium of renal pelvis. Reverse transcription linked to PCR applied to microdissected nephron segments indicated the presence of rTX receptor mRNA exclusively in the glomerulus. In conclusion, we have cloned a functional rat kidney $\mathbf{T X}$ receptor, which is expressed specifically in renal glomerulus, arterial smooth muscle cells, and transitional cell epithelium of renal pelvis. The present study will provide important insights into the etiology and pathophysiology of renal diseases with relation to TX metabolism. ( $J$. Clin. Invest. 1995. 96:657-664.) Key words: in situ hybridization - reverse transcription-PCR - calcium signal transduction • nephron segments $\bullet$ renal pelvis
\end{abstract}

Portions of this study were presented at the 26th Annual Meeting \& Exposition for the American Society of Nephrology, 14-17 November 1993 in Boston, MA; at the 15th Biennial Scientific Meeting of the International Society of Hypertension, 20-24 March 1994 in Melbourne, Australia; and have appeared in abstract form (1993. J. Am. Soc. Nephrol. 4:481. and 1994. J. Hypertens. 12:S66.).

Address correspondence to Kazuhisa Takeuchi, the Second Department of Internal Medicine, Tohoku University School of Medicine, 11 Seiryo-machi, Aoba-ku, Sendai 980-77, Japan. Phone: 81-22-2741111, x2520; FAX: 81-22-274-5332.

Received for publication 27 June 1994 and accepted in revised form 13 April 1995.

J. Clin. Invest.

(c) The American Society for Clinical Investigation, Inc.

0021-9738/95/08/0657/08 \$2.00

Volume 96, August 1995, 657-664

\section{Introduction}

Thromboxane (TX) ${ }^{1} A_{2}$ is a metabolite of arachidonic acid, which evokes smooth muscle constriction and platelet aggregation (1). In the kidney, $\mathrm{TXA}_{2}$ has been shown to decrease renal blood flow (2) and glomerular filtration rate (3), and to potentiate tubuloglomerular feedback (4), thus involved in the control of renal hemodynamics and water and electrolyte metabolism. TXA $_{2}$ is also implicated in the etiology or pathophysiology of many renal diseases such as nephritis (5-7), allograft transplantation rejection (8), and urinary tract obstruction (9). Blockade of TX synthase activity or TXA ${ }_{2}$ receptor binding has been shown to prevent exacerbation of renal injury caused by these diseases $(9-13)$.

Biological action of TX is exerted via its specific receptor present on the cell surface (1). Recently, TX receptor cDNA has been isolated from human placenta (14), human endothelial cells (15), or mouse lung (16). The receptor structure contains seven transmembrane domains characteristic of $G$ protein-coupled receptors, and the functional study has indicated that this receptor is linked with inositol trisphosphate $\left(\mathrm{IP}_{3}\right) / \mathrm{Ca}^{2+}$ signal transduction. The receptor mRNA is expressed mainly in the brain, thymus, heart, liver, spleen, uterus, and in the kidney. In isolated renal glomeruli $(3,17)$, cultured renal glomerular mesangial cells $(18,19)$, and epithelial cells of urinary bladder (20), TX has previously been shown to induce an increase in intracellular free calcium $\left(\left[\mathrm{Ca}^{2+}\right] \mathrm{i}\right)$. These observations suggest that in the kidney there may be a functional TX receptor which is coupled to $\mathrm{Ca}^{2+}$ messenger system. The structure of kidney TX receptor, however, has not been revealed. We, therefore, decided to isolate kidney TX receptor CDNA and its possible isoform. Using this cloned cDNA, we examined signal transduction of the receptor, and expression of mRNA in the kidney either by in situ hybridization or by reverse transcription linked to PCR (RT-PCR) applied to microdissected nephron segments.

\section{Methods}

Materials. AZAPII phage vector and pBlueScript II were from Stratagene, Inc. (San Diego, CA). Thermus aquaticus ( $T a q)$ polymerase, T7 RNA polymerase and restriction enzymes were obtained from Takara Shuzo, Co., Ltd. (Kyoto, Japan). Hybon $\mathrm{N}^{+}$blotting membranes and $\beta$-Max film were from Amersham Corp. (Arlington Heights, IL). $\left[{ }^{3} \mathrm{H}\right]$ SQ29548 was from Dupont-New England Nuclear (Boston, MA). Oligonucleotides were synthesized by Sawady, Inc. (Tokyo, Japan). An expression vector, pcDNAI/Amp, was obtained from Invitrogen (San Diego, CA). NTB2, from Eastman Kodak Co. (Boston, MA). Fura-2/

1. Abbreviations used in this paper: ang, angiotensin; $\left[\mathrm{Ca}^{2+}\right] \mathrm{i}$, intracellular-free calicium; GAPDH, glyceraldehyde-3-phosphate dehydrogenase; RT-PCR, reverse transcription PCR; rTX, rat thromboxane; TX, thromboxane. 


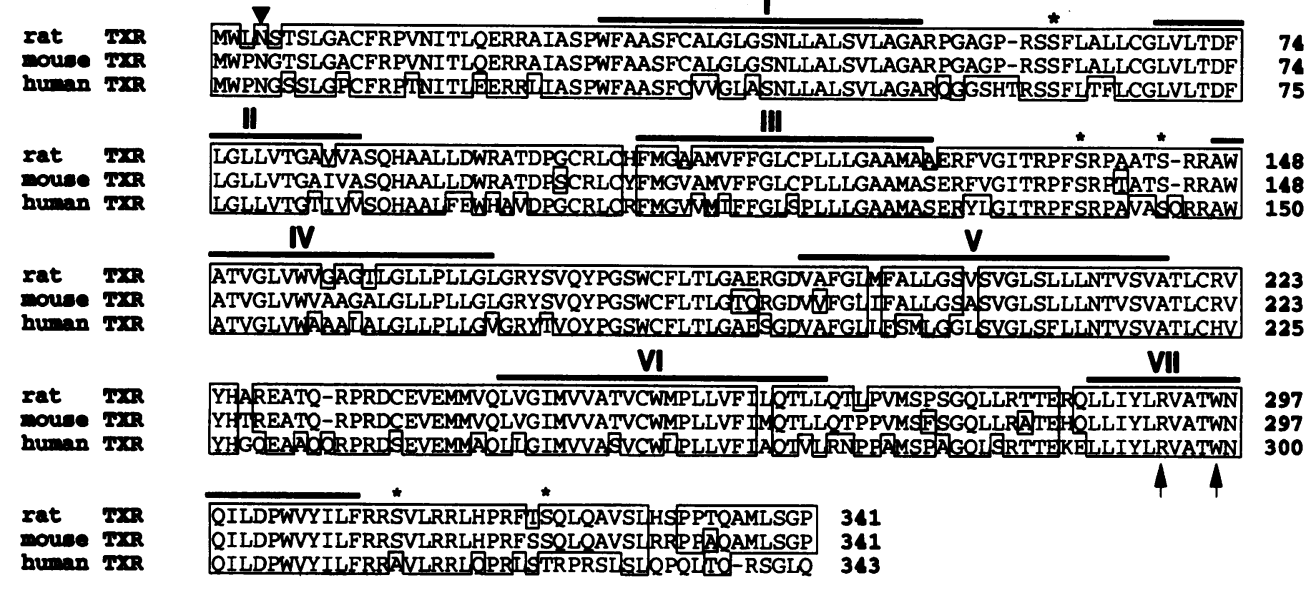

Figure 1. Amino acid sequence comparison of rat, mouse, and human thromboxane $A_{2}$ receptor (TXR). The three sequences are aligned with single letter notation by inserting gaps (-) to achieve maximum homology. The seven putative transmembrane segments (I-VII) were assigned on the basis of hydrophobicity analysis. The termini of these segments are tentatively defined. Other marks are as follows: triangle, potential $N$-glycosylation site; stars, possible phosphorylation sites. Arg292 and Trp-296 are indicated by arrows. The nucleic acid sequence coding rat TXR has been deposited in the DDBJ/GenBank ${ }^{\mathrm{TM}}$ / EMBL databases under accession number D21158.
AM was obtained from Dotite (Kumamoto, Japan). Ionomycin was from Calbiochem-Behring Corp. (San Diego, CA). U46619 and SQ29548 were from Cayman Chemical Co. Inc. (Ann Arbor, MI). Angiotensin (ang) II from Peptide Institute (Osaka, Japan). KW3635 ( $\operatorname{sodium}(E)-11-[2-(5,6-d i m e t h y l-1-b e n z i m i d a z o l y l)-e t y l i d e n e]-6,11-$ dihydro-dibenz-[b,e] oxepin-2-carboxylate-mono-hydrate) $(21,22)$ was a gift from Kyowa Hakko Kogyo, Co., Ltd. (Tokyo, Japan). cDNA encoding mouse thromboxane receptor (15) was a gift from Dr. S. Narumiya, Kyoto University School of Medicine, Kyoto, Japan. cDNA (Ca18b) encoding rat angiotensin II $\mathrm{AT}_{1 \mathrm{a}}$ receptor (23) was provided by Dr. T.J. Murphy, Emory University School of Medicine, Atlanta, GA.

cDNA cloning. cDNA library was constructed from fractions containing more than 1-kb pair cDNAs with $\lambda$ ZAPII vector as previously described (24). Three hybridization positive clones were finally isolated, and rescued into pBlueScript SK(-) with helper phage R408. The cDNA inserts of these clones showed an identical restriction enzyme digestion pattern, and one clone (rTXR2) was chosen for further sequence analysis. The sequence was determined in both directions by dideoxy chain-termination method.

Electrophysiological analysis in Xenopus oocytes. Electrophysiological analysis in Xenopus oocytes was performed by a previously reported method (24). Briefly, the prTXR2 clone was linearized with NotI. Capped mRNA ( $50 \mathrm{ng}$ ) was synthesized with T7 RNA polymerase, and injected into Xenopus oocytes. Whole cell currents were measured by a two microelectrode voltage clamp method.

Cell culture. COS-7 cells were cultured with DME supplemented with 10\% FBS and penicillin-strepomycin (GIBCO-BRL, Gaithersburg, MD) in a humidified condition with $5 \% \mathrm{CO}_{2}$ in air at $37^{\circ} \mathrm{C}$. Rat glomerular mesangial cells were obtained by a previously reported method $(25,26)$, and cultured with RPMI/L40 (GIBCO-BRL) with $10 \%$ FBS and penicillin-streptomycin. Passages six to nine were used for the experiments.

Transient expression in COS-7 cells. EcoRI cDNA fragment of rTXR2 $(\sim 1.8 \mathrm{~kb})$ or rat vascular angiotensin II $\mathrm{AT}_{1 \mathrm{a}}$ receptor cDNA $(\sim 2.2 \mathrm{~Kb})$ were subcloned into pcDNAI/Amp, designated pcDNAIrTXR2, or pcDNAI-AT $1 \mathrm{a}$, respectively. The plasmid for transfection was prepared by alkaline lysis of bacterial cultures, and the supercoil plasmid DNA was obtained by cesium chloride gradient. $25 \mu \mathrm{g}$ of pcDNAI-rTX2 and $25 \mu \mathrm{g}$ of pcDNAI-AT ${ }_{1 \mathrm{a}}$ was cotransfected into COS7 cells cultured on coverglass by the calcium phosphate method as previously reported (27). pcDNAI-AT $T_{1 \mathrm{a}}$ is used as a positive control for transfection in analysis of calcium signal transduction.

Binding analysis. Receptor binding analysis was performed using the COS-7 cells transiently expressed with pcDNAI-rTXR2 $(25 \mu \mathrm{g})$ by the previously reported method $(14,15,28)$.

Measurement of intracellular calcium with fura-2/AM. Cytosolicfree calcium was measured with fura-2/AM in transfected COS-7 cells cultured on coverglass by a modification of previously reported methods (29-31) with a fluorometer (CAF-100; Nihon-Bunko Co., Ltd., Tokyo, Japan) at excitation wavelength of $340 \mathrm{~nm}$ and emission wavelength of $500 \mathrm{~nm}$.

In situ hybridization. In situ hybridization was performed by a previously reported method $(24,28)$ with a 850 -bp BglII-BglII fragment of radiolabeled cRNA. The hybridized sections were exposed to $\beta$-Max film for $28 \mathrm{~d}$. For microscopic analysis, the sections were dipped into NTB2 diluted 1:1 with distilled water, developed after $12 \mathrm{w}$ exposure, and then counterstained with hematoxylin and eosin.

RT-PCR using microdissected nephron segments. Microdissection (32) and RT-PCR with the microdissected nephron segments were performed by previously reported methods $(33,34)$. Briefly, nephron segments were from glomerulus, proximal tubule, cortical thick ascending limb of Henle's loop, and cortical collecting duct. To digest genomic DNA, mRNA samples from nephron segments were treated with RNasefree DNase I (Sigma Chemical Co., St. Louis, MO). To distinguish PCR amplification of contaminated genomic DNA, samples without reverse transcription were also prepared. To amplify the rat $\mathrm{TX}$ receptor cDNA fragment, the following oligonucleotides were used as primers: 5'-TGGACTGGCGTGCCACTGAT-3' (sense primer, position 275294) and 5'-AGCAAGGGCATCCAACACACCGTG-3' (antisense primer, position 753-776). A fragment of rat cDNA for ubiquitous glyceraldehyde-3-phosphate dehydrogenase (GAPDH) was also amplified with the same samples simultaneously in different tubes with the following oligonucleotides (GAPDH primers): 5 '-TCCCTCAAGATTGTCAGCAA-3' (from position 506 to 525 and 5'-AGATCCACAACGGATACATT-3' (position 795-814) (35). Moreover, RT-PCR was also applied to examine mRNA expression of rat angiotensin II $\mathrm{AT}_{\mathrm{la}}$ receptor along nephron segments. The primers for $\mathrm{AT}_{1 \mathrm{a}}$ receptor cDNA amplification were: 5'-TCCTGTTCCACCCGATCACCGATCA-3' (sense primer, position -230 to -206 , located in the second exon) and 5'-CTTCAGCAGAAGAGTTAAGGGCCAT-3' (antisense primer, position 1 to 25 , located in the third exon) $(23,27)$. For PCR amplification, total PCR volume was $50 \mu \mathrm{l}$ which contained $50 \mathrm{pmol}$ of each primers, $1.25 \mathrm{mM}$ deoxynucleotide mixture, $2.5 \mathrm{U}$ Taq DNA polymerase, $10 \mathrm{mM}$ Tris- $\mathrm{HCl}$ ( $\mathrm{pH} 8.3$ ), $50 \mathrm{mM} \mathrm{KCl}, 1.5 \mathrm{mM} \mathrm{MgCl}_{2}$, $0.001 \%(\mathrm{wt} / \mathrm{vol})$ gelatine. PCR was carried out by the following protocol: 1 min of denaturation at $94^{\circ} \mathrm{C}, 2 \mathrm{~min}$ of annealing at $60^{\circ} \mathrm{C}$, and 2 

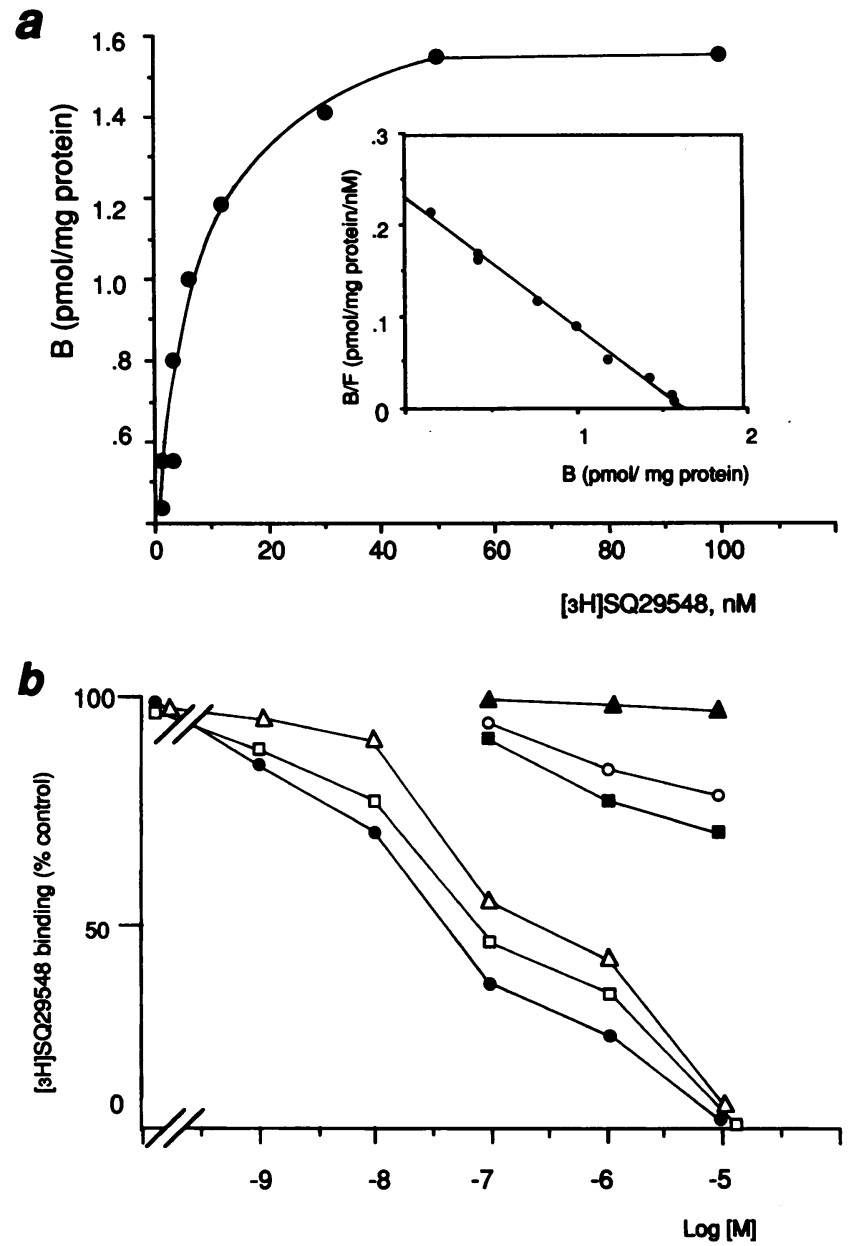

Figure 2. Binding characteristics of rTX receptor. $a$ shows saturation of the specific binding of the TXA ${ }_{2}$ antagonist $\left[{ }^{3} \mathrm{H}\right] \mathrm{SQ} 29548$ to membranes from COS-7 cells transiently transfected with pcDNA-rTXR2. Membrane $(100 \mu \mathrm{g})$ of COS-7 cells were incubated with several concentrations of $\left[{ }^{3} \mathrm{H}\right] \mathrm{SQ} 29548 . b$ shows displacement of the binding of $\left[{ }^{3} \mathrm{H}\right]-$ SQ29548 with other prostaglandins or $\mathrm{TXA}_{2}$ mimetics. Displacement

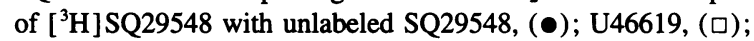

$\mathrm{KW} 3635,(\Delta) ; \mathrm{PGE}_{2},(\square)$; $\mathrm{PGF}_{2 \alpha},(0) ; \mathrm{PGD}_{2},(\Delta)$. The results shown here are representative of three similar experiments with each point indicating the mean of four determinations.

min of extension at $72^{\circ} \mathrm{C}$, for 40 cycles. The PCR products were resolved in a $1.5 \%$ agarose gel, transferred to a Hybond $\mathrm{N}^{+}$nylon membrane, and the membrane was hybridized with radiolabeled rTXR2 cDNA in a solution containing $50 \%$ formamide, $5 \times \mathrm{SSC}, 5 \times$ Denhardt's solution, $1 \%$ SDS at $42^{\circ} \mathrm{C}$ overnight. The membrane was then washed with a solution containing $0.1 \times \mathrm{SSC}$ and $0.1 \% \mathrm{SDS}$ at $65^{\circ} \mathrm{C}$, and exposed to a film for $12 \mathrm{~h}$.

Molecular biology procedures used in the present experiments were according to the standard protocols (36), unless otherwise indicated.

\section{Results}

Receptor structure. Fig. 1 shows the predicted amino acid sequence of rTXR2. The sequence consists of 341 amino acids with calculated molecular weight of 36925.71. Hydropathy analysis (37) has shown eight hydrophobic segments in the protein structure. The first one is located at the amino terminus, a
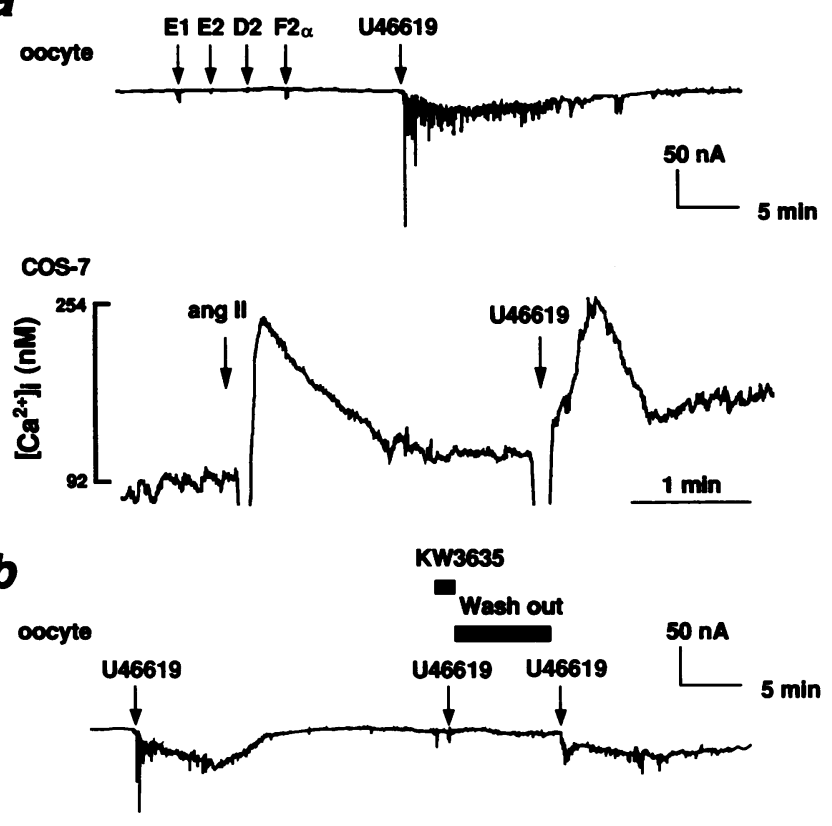

$\cos -7$

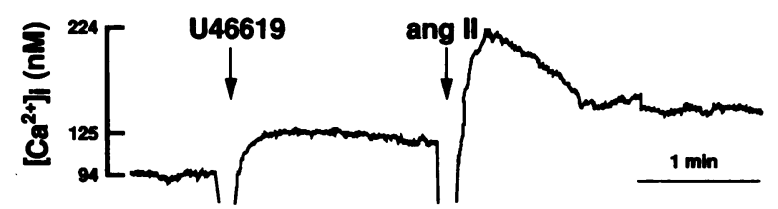

Figure 3. Functional expression of rTXR2 in COS-7 cells and Xenopus oocytes. Upper figures in Fig. 2, $a$ or $b$ show traces of currents recorded from oocytes injected with the in vitro synthesized mRNA from rTXR2. Response to $\mathrm{U} 46619(0.1 \mu \mathrm{M})$ was recorded under voltage clamp at $-60 \mathrm{mV}$ after $2 \mathrm{~d}$ incubation of the oocyte injected with $\sim 20 \mathrm{ng}$ of the rat rTXR2 mRNA. Downward deflection indicates inward currents. Lower figures represent changes in intracellular $\mathrm{Ca}^{2+}\left(\left[\mathrm{Ca}^{2+}\right] i\right)$ measured by fura- 2 method in monolayer of COS-7 cells which were cotransfected with rTXR2 and ang II AT 1 receptor cDNA. U46619 and ang II were sequentially added. Each result was representative of three reproduced observations. U46619, $1 \mu \mathrm{M}$; ang II, $10 \mathrm{nM}$; KW3635, 0.1 $\mathrm{mM}$. The experiment was performed in the absence (control) $(a)$ or in the presence of KW3635 $(b)$ Maximum $\left(F_{\max }\right)$ and minimum fluorescence $\left(F_{\min }\right)$ were obtained by addition of $2 \mu \mathrm{M}$ ionomycin and subsequent addition of $2.5 \mathrm{mM}$ EGTA, respectively.

and may indicate a signal peptide (38). The following hydrophobic segments may form the structure of seven transmembrane domains characteristic of $\mathrm{G}$ protein-coupled receptors. The amino acid sequence of rTXR2 is highly homologous to human placenta (75.7\% identity) (14) or mouse TX receptor (92.7\% identity) (16) (Fig. 1), and the clone was considered to encode rat TX (rTX) receptor. In the rat TX receptor, Arg292 , which has been suggested to be important for ligand binding (14), and Trp-296, which has been shown to allow a definite discrimination between agonist and antagonist (39), are conserved. One potential $N$-glycosylation site (40), and five serine residues (Ser-61, -138, -144, -311, and -322) for possible phosphorylation in the cytoplasmic regions (41) are assigned.

Receptor binding assay. The membrane of transient transfectant revealed saturating $\left[{ }^{3} \mathrm{H}\right] \mathrm{SQ} 29548$ binding. Scatch- 
2
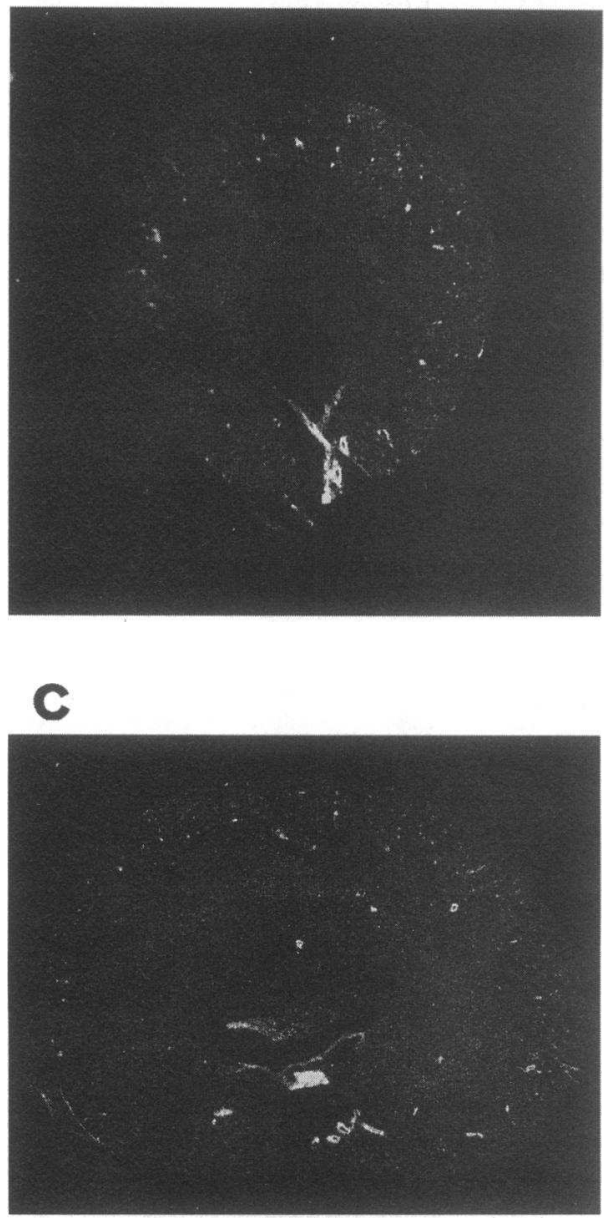
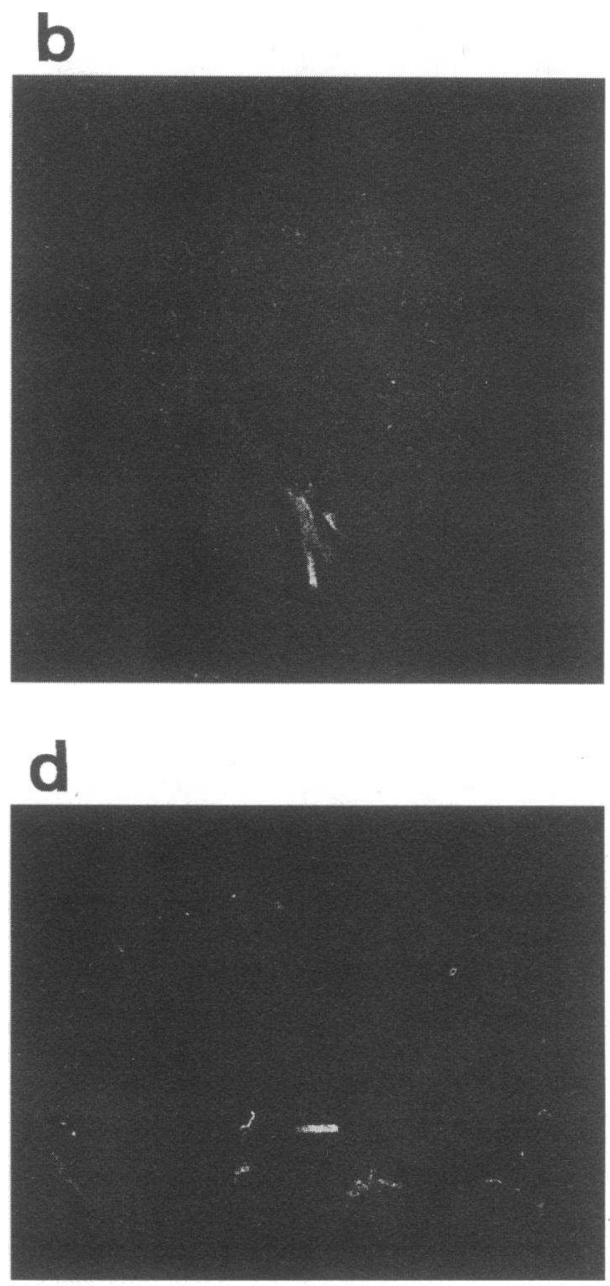

Figure 4. In situ hybridization of rat kidney TX receptor mRNA in the kidney. Negative film images of coronal sections of rat kidney $a$ and $b$ and sagittal sections $c$ and $d$ are shown. White regions indicate mRNA expression ( $b$ and $d$ ) displacement of radiolabeled cRNA by an excess of unlabeled cRNA. ard analysis revealed a single class of binding site with $\mathbf{B}_{\max }$ of $1.4 \mathrm{pmol} / \mathrm{mg}$ protein and $K_{\mathrm{d}}$ value of $1.1 \mathrm{nM}$ (Fig. $2 a$ ). The binding with $\left[{ }^{3} \mathrm{H}\right] \mathrm{SQ} 29548$ was displaced with an unlabeled SQ29548 (TX receptor antagonist), U-46619 (TX receptor agonist), or KW-3635 (TX receptor antagonist) with $50 \%$ inhibitory concentration of $0.48,0.95$, or $1.28 \times 10^{-7} \mathrm{M}(n=4)$, respectively (Fig. $2 b$ ). The binding, however, was not significantly inhibited by $\mathrm{PGE}_{2}, \mathrm{PGF}_{2 \alpha}$, or $\mathrm{PGD}_{2}$. These binding characteristics are in good agreement with those of human and mouse TX receptors $(14,16)$.

Signal transduction. Signal transduction of cloned rTX receptor was investigated by either Xenopus oocyte expression or transient expression in COS-7 cells. In the Xenopus oocyteinjected with rTX receptor mRNA, U46619 induced potent and long-lasting currents characteristic of the receptors linked with $\mathrm{IP}_{3} / \mathrm{Ca}^{2+}$ signal transduction (42) (Fig. $3 a$, top). Application of $\mathrm{PGE}_{1}, \mathrm{PGE}_{2}, \mathrm{PGD}_{2}$ or $\mathrm{PGF}_{2 \alpha}(0.1 \mathrm{mM}$ each $)$ had no effect on the oocyte. Consistent with this observation, in COS-7 cells transfected with both $\mathrm{rTX}$ and $\mathrm{AT}_{1 \mathrm{a}}$ receptor cDNAs, U46619 $(1 \mu \mathrm{M})$ induced an increase in cytosolic free calcium $\left(\left[\mathrm{Ca}^{2+}\right] \mathrm{i}\right)$ (from $96 \pm 8$ to $240 \pm 18 \mathrm{nM}, n=5$ ), and ang II ( $10 \mathrm{nM}$ ) also induced an increase in $\left[\mathrm{Ca}^{2+}\right]$ i. (Fig. $3 \mathrm{a}$, bottom). Application of either U46619 $(1 \mu \mathrm{M})$ or ang II $(10 \mathrm{nM})$ did not change $\left[\mathrm{Ca}^{2+}\right] \mathrm{i}$ in COS-7 cells without transfection (data not shown). We next examined the effect of a TX receptor antagonist,
KW3635. As shown in Fig. $3 b$ (top), in the oocyte, KW3635 markedly inhibited U46619-induced currents. After washing out KW3635, currents were recovered. In COS-7 cells transfected with both $\mathrm{rTX}$ and $\mathrm{AT}_{1 \mathrm{a}}$ receptor cDNAs, pretreatment with KW3635 $(0.1 \mathrm{mM})$ inhibited U46619 (1 $\mu \mathrm{M})$-induced increase in $\left[\mathrm{Ca}^{2+}\right] \mathrm{i}$, whereas the increase in $\left[\mathrm{Ca}^{2+}\right] \mathrm{i}$ by ang II $(10 \mathrm{nM}$ ) was not inhibited (Fig. $3 \mathrm{~b}$, bottom). Thus, coupling of rTX receptor to calcium signal transduction system was confirmed.

In situ hybridization. As shown in Fig. 4, $a$ and $c$, mRNAs for rTX receptor (white dots) were detected principally in the renal cortex. Interestingly, remarkable expression of mRNA was also observed in the renal pelvis. Specific hybridization was confirmed by displacement of signals with an excess of unlabeled cRNA (Fig. 4, $b$ and $d$ ). Microscopic examination has shown that rTX receptor mRNA is present at glomeruli, and arterial walls (probably at smooth muscle cells) in the cortex region (Fig. 5, $a$ and $b$ ). In the renal pelvis, rTX receptor mRNA was observed in the transitional cell epithelium (Fig. $5 c)$.

Localization of $r T X$ receptor mRNA along nephron segments. In the experiments, mRNA samples was treated with RNase-free DNase I to digest genomic DNA which might possibly be contaminated. Moreover, specific RT-PCR amplification of mRNA was distinguished by the results obtained by treatment 


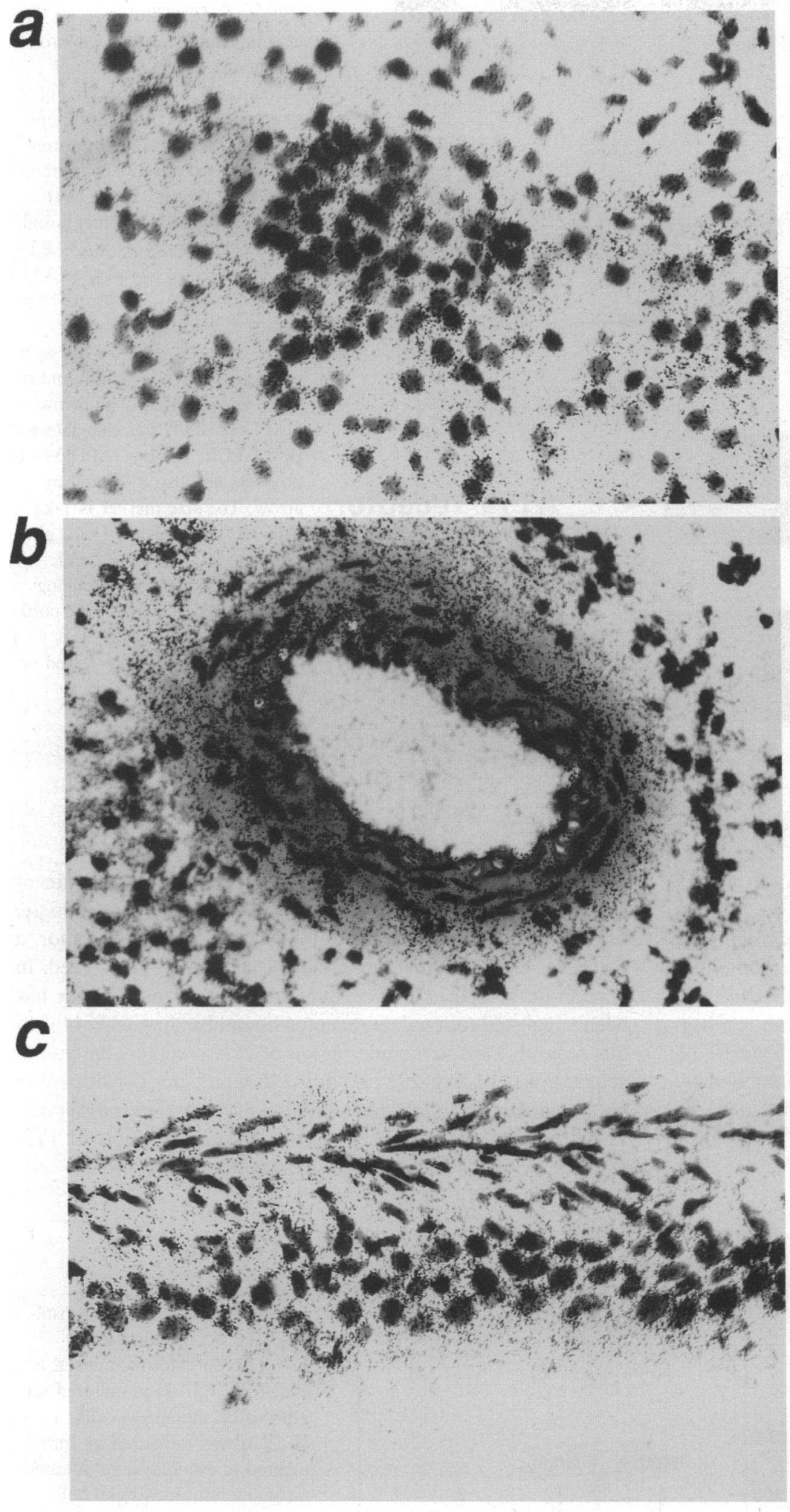

Figure 5. Cellular localization of rat TX receptor mRNA. Bright-field photographs of emulsified-dipped sections of the kidney in in situ hybridization. The sections were counterstained by hematoxylin and eosin. (a) glomerular region; $(b)$ renal arteriole, $(c)$ renal pelvis. Dotted black grains indicate mRNA expression. or no treatment with reverse transcriptase. PCR product with expected size was only detected in glomerulus sample treated with RT (+), and this product was hybridized with a radiolabeled rTX receptor cDNA (Fig. $6 a$ ). On the other hand, RTPCR product was not detected either in samples without treatment with RT (-) or in RT (+) samples of proximal tubule, cortical thick ascending limb of Henle's loop, and cortical collecting duct. Ubiquitous GAPDH mRNA was expectedly detected in all RT (+) tubule samples (Fig. $6 c$ ). Different from the expression of $\mathrm{rTX}$ receptor, PCR product for $\mathrm{AT}_{1 \mathrm{a}}$ receptor mRNA was detected in every samples with reverse transcription (Fig. 6 b). Samples without RT (-) gave no $\mathrm{AT}_{1 \mathrm{a}}$ receptor 


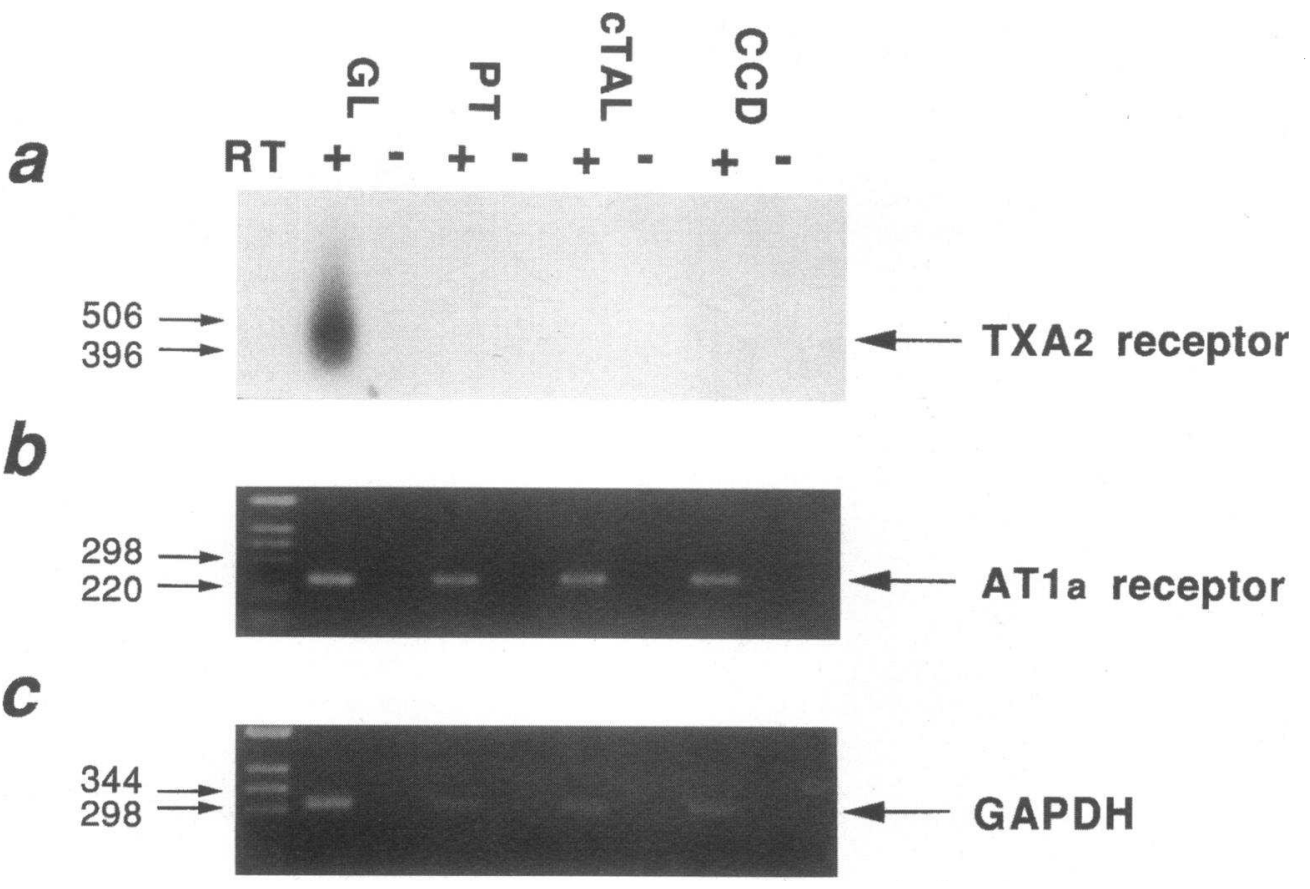

Figure 6. Distribution of rat TX receptor mRNA along nephron segments. RT-PCR was performed with microdissected nephron segments. (a) The 502-bp PCR product in a $1.5 \%$ agarose gel was analyzed by Southern blot with radiolabelled $\mathrm{rTXR2}$. The

TX receptor PCR product is indicated by an arrow. $b$ shows RTPCR analysis of angiotensin AT1a receptor mRNA. 255-bp AT1a receptor PCR products (white bands) are shown in a $1.5 \%$ agarose gel stained with ethidium bromide as indicated by an arrow. GAPDH mRNA was also detected by RT-PCR. 308-bp GAPDH PCR products are also indicated by an arrow. The size marker is $1-\mathrm{kb}$ ladder (GIBCO-BRL). GL, glomerulus; PT, proximal tubule; cTAL, cortical thick ascending limb of Henle's loop; CCD, cortical collecting duct. RT (+) or (-) represents the samples treated or untreated with reverse transcriptase, respectively.
PCR product. Thus, the results indicate that $\mathrm{rTX}$ receptor is exclusively localized to the glomerulus, whereas $\mathrm{AT}_{1 \mathrm{a}}$ receptor is widely distributed along nephron segments distinct from rTX receptor expression.

Calcium signals in cultured rat glomerular mesangial cells. To confirm functional rTX receptor in the renal glomerular cells, rat glomerular mesangial cells were cultured and calcium signal was examined in the cells. Consistent with the result in functional expression with cloned rTX receptor, U46619 (1 $\mu M)$ induced an increase in $\left[\mathrm{Ca}^{2+}\right] \mathrm{i}$, which was inhibited by KW3635 (0.1 mM) (Fig. 7, $a$ and $b)$. Ang II (10 nM) (a positive control) also induced an increase in $\left[\mathrm{Ca}^{2+}\right] \mathrm{i}$, which was not affected by KW3635 treatment.

\section{Discussion}

Rat kidney TX receptor is suggested to have the structure of seven transmembrane spanning domains, which is characteristic of $\mathrm{G}$ protein-linked receptors (Fig. 1). In this rTX receptor, a couple of characteristic amino acid structures are conserved. In adrenergic receptors, the seventh transmembrane domain has been suggested to regulate receptor-ligand binding $(43,44)$. In this seventh transmembrane region of rTX receptor, the amino acid residues of Arg-292 and Trp-296 which are considered to be crucial for specific ligand binding $(14,39)$ are conserved. The amino acid structure of third cytoplasmic loop of rTX receptor, which is suggested to be important for G protein cou-
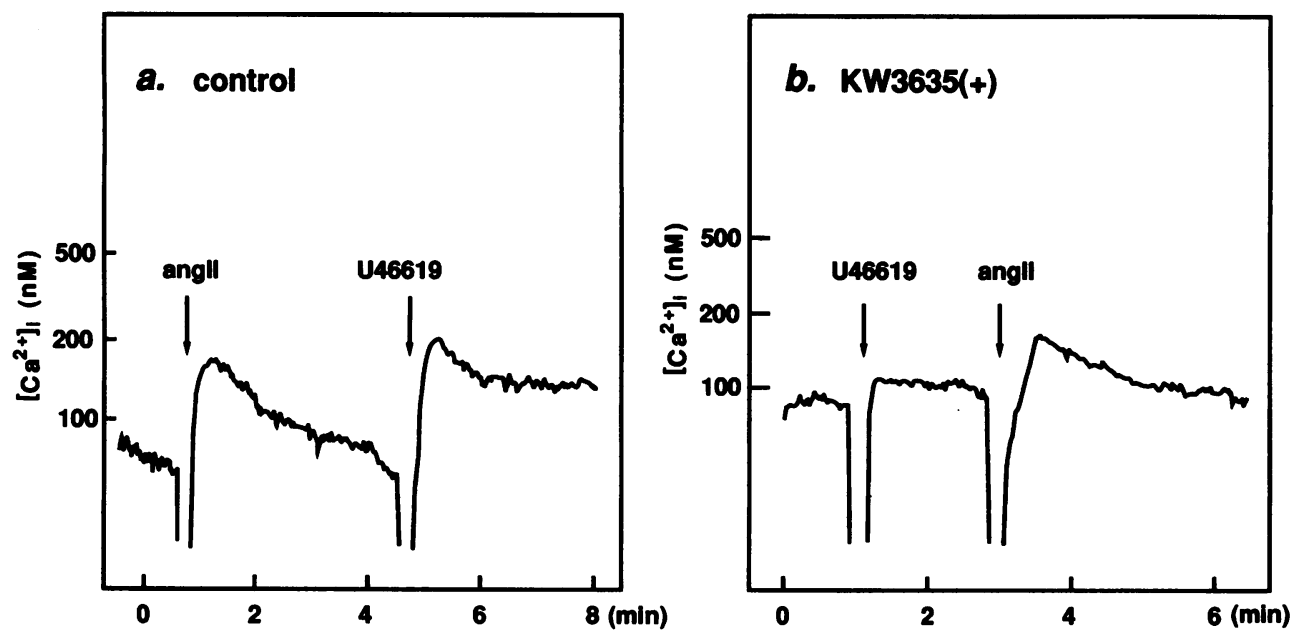

Figure 7. Effect of a nonprostanoic TX receptor antagonist KW3635 on U46619-induced increase in $\left[\mathrm{Ca}^{2+}\right] \mathrm{i}$ in cultured rat glomerular mesangial cells. $\left[\mathrm{Ca}^{2+}\right] \mathrm{i}$ was measured by fura- 2 method in monolayer of cultured rat glomerular mesangial cells. U46619, $1 \mu \mathrm{M}$; KW-3635, 0.1 $\mathrm{mM}$; ang II, $10 \mathrm{nM}$. Stimulants were sequentially added at the points indicated by arrows in the absence (control) $(a)$ or presence of KW3635 $(0.1 \mathrm{mM})(b)$, respectively. Each result was representative of three reproduced observations. 
pling (45), is also highly conserved. These conserved amino acid residues or domains may determine ligand specificity and/ or selective interaction with a $G$ protein. In agreement with the previous report, the ligand binding study demonstrated the specific binding of the rat kidney TX receptor to TX mismatches as shown in Fig. 2.

In platelets, TX receptor has been shown to be linked to $\mathrm{IP}_{3} / \mathrm{Ca}^{2+}$ signal transduction pathway (46). In the present study, oocytes injected with rTX receptor mRNA showed currents indicating $\mathrm{Ca}^{2+}$-induced $\mathrm{Cl}^{-}$currents (Fig. 3). Moreover, we have demonstrated an increase in $\left[\mathrm{Ca}^{2+}\right] \mathrm{i}$ by a TX mimetic U46619 in COS-7 cells transfected with cloned rTX receptor cDNA. Thus, consistent with the previous reports (14-16, 24, 46), rat kidney $\mathrm{TX}$ receptor is suggested to be linked with $\mathrm{IP}_{3} /$ $\mathrm{Ca}^{2+}$ signal transduction system.

TX receptor linked with $\mathrm{Ca}^{2+}$ signal transduction has been shown to be present in rat renal glomerular mesangial cells (17, 18). In the present study, we also confirmed the presence of functional receptor in rat mesangial cells (Fig. 7). Similar to the result in cultured rat vascular smooth muscle cells (47), KW3635 specifically inhibited U46619-induced increase in $\left[\mathrm{Ca}^{2+}\right]$ i. Moreover, consistent with the results of binding study, we have also shown that U46619-induced increase in $\left[\mathrm{Ca}^{2+}\right] \mathrm{i}$ is inhibited by KW3635 in COS-7 cells transfected with cloned rTX receptor cDNA (Fig. 3). Both in situ hybridization and RT-PCR applied to microdissected nephron segments have indicated the localized expression of rTX receptor mRNA to the glomerulus (Figs. 4-6). The presence of rTX receptor mRNA was also observed in smooth muscle cells of renal arterioles (Fig. 5). It is, therefore, suggested that the same TX receptor is expressed in mesangial cells as well as in vascular smooth muscle cells. Our observations, however, do not exclude a possible isoform in the glomerulus proposed by pharmacological studies (19), although we did not find a cDNA different from rTXR2.

By RT-PCR applied to microdissected nephron segments, we detected rTX receptor mRNA in the sample from glomeruli treated with reverse transcriptase, while no PCR product was detected in other nephron segments (Fig. $6 a$ ). Using the same sample, we also detected a GAPDH PCR product consistently in every nephron segments only when treated with reverse transcriptase. This observation indicates that the targeted mRNA was specifically amplified, and contamination of genomic DNA was neglected. Moreover, we examined expression of mRNA for ang II $\mathrm{AT}_{1 \mathrm{a}}$ receptor. Since the primers used in the experiment are derived from separate exons (27), the PCR product of expected size indicates the product specific to $\mathrm{AT}_{1 \mathrm{a}}$ receptor mRNA. As shown in Fig. $6 b, \mathrm{AT}_{1 \mathrm{a}}$ receptor mRNA is expressed in most nephron segments including glomerulus, consistent with other reports $(34,48)$. Thus, both $\mathrm{rTX}$ receptor and $\mathrm{AT}_{1 \mathrm{a}}$ receptor are shown to be expressed in the glomerulus, and these results have suggested that these vasoconstrictor hormone receptors mediate constriction of glomerular mesangial cells via $\mathrm{Ca}^{2+}$ messenger, and are involved in control of glomerular filtration rate by affecting ultrafiltration coefficient $\left(K_{\mathrm{f}}\right)$. In renal tubules, however, we did not detect rTX receptor mRNA expression by either in situ hybridization or RT-PCR (Figs. 4-6). So far, it has not been clarified that TX receptor with a biological action is present at renal tubules. We, however, do not absolutely deny the existence of rTX receptor in tubules because the sensitivity of our RT-PCR procedure might not be enough.
Analyses using antibody against rTX receptor are required to further appraise the expression of rTX receptor along nephron segments.

Different from the mRNA expression of TX receptor, $\mathrm{AT}_{1 \mathrm{a}}$ receptor mRNA was detected in every nephron segments. Tubular function of $\mathrm{AT}_{1 \mathrm{a}}$ receptor is little known except the effect of ang II on sodium metabolism in proximal tubules (49). In other nephron segments, no conclusive study on tubular ang II response has been reported. As ang II has recently been shown to be a growth factor in the kidney $(50)$, tubular $\mathrm{AT}_{1 \mathrm{a}}$ receptor may possibly be involved in cell growth of renal tubules or its related effects. In any events, we observed the differential expression between $\mathrm{AT}_{1 \mathrm{a}}$ and $\mathrm{rTX}$ receptor mRNA along nephron segments suggesting tissue (tubulus)-specific expression of vasoactive hormone receptors. Comparative analysis between 5 '-flanking transcription regulatory region of $\mathrm{AT}_{1 \mathrm{a}}$ receptor gene (27) and that of rTX receptor gene (the structure analysis is under progress) may possibly clarify a molecular mechanism of the differential expression.

In the transitional cell epithelium of renal pelvis, we detected mRNA for TX receptor significantly (Figs. 4 and 5). It has been reported that there is a functional TX receptor linked with $\mathrm{Ca}^{2+}$ signal transduction pathway in epithelial cells of toad urinary bladder, and the TX action is shown to modulate the response to vasopressin $(20,51)$. The expression of TX receptor in the renal pelvis may possibly be involved in this function of TX receptor in the urinary bladder.

In summary, we have cloned the functional rat kidney TX receptor, which is linked with $\mathrm{IP}_{3} / \mathrm{Ca}^{2+}$ signal transduction. In situ hybridization has shown that TX receptor mRNA is present in smooth muscle cells of renal arterioles, glomeruli, and transitional cell epithelium of the renal pelvis. RT-PCR with microdissected nephron segments has shown that rTX receptor mRNA is exclusively present in the glomerulus probably in mesangial cells. Distinct from TX receptor, $\mathrm{AT}_{1 \mathrm{a}}$ receptor is expressed in most of renal tubules, indicating differential tissuespecific expression of vasoactive receptors. The expression of rTX receptor in the transitional cell epithelium of renal pelvis may provide a new insight into the functional role of TX receptor in the kidney. The present observations are important for further examination of the role of TX receptor involved in the physiology or pathophysiology of kidney.

\section{Acknowledgments}

We are thankful to Dr. Kazuhiro Murakami, Department of Pathology I, Tohoku University School of Medicine, for technical assistance in in situ hybridization, and to Dr. Mitsuhiko Yanai, Department of Pharmacology I, Tohoku University School of Medicine, for advice in receptor binding assays.

This study is supported in part by a grant-in-aid (No. 06671124) from the Ministry of Education, Science, and Culture, Japan (K. Takeuchi), and a grant from the Takeda Foundation for Research on Metabolic Disorder, Japan (K. Takeuchi). T. Abe is a recipient of fellowship from the Japan Society for the Promotion of Science for Junior Scientists.

\section{References}

1. Coleman, R. A., I. Kennedy, P. A. Humphry, K. Bunke, and P. Lumley. 1989. Prostanoids and their receptors. In Comprehensive Medical Chemistry, vol. 3, Membranes and Receptors. J. C. Emmett, editor. Pergamon Press Ltd., Oxford, United Kingdom, 643-714. 
2. Cirino, M., H. Morton, C. MacDonald, J. Hadden, and A. W. Ford-Hutchinson. 1990. Thromboxane $A_{2}$ and prostaglandin endoperoxide analogue effects on porcine renal blood flow. Am. J. Physiol. 258:F109-F114.

3. Wilkes, B. M., J. Solomon, M. Maita, and P. F. Mento. 1989. Characterization of glomerular thromboxane receptor sites in the rat. Am. J. Physiol. 256:F111F1116.

4. Welch, W. J., and C. S. Wilcox. 1992. Potentiation of tubuloglomerular feedback in the rat by thromboxane mimetic: role of macula densa. J. Clin. Invest. 89:1857-1865.

5. Kelly, V. E., S. Sneve, and S. Musinski. 1986. Increased renal thromboxane production in murine lupus nephritis. J. Clin. Invest. 77:252-259.

6. Patrono, C., G. Ciabattoni, G. Remussi, E. Gotti, S. Bombardieri, O. DiMunno, G. Tartarelli, G. A. Cinotti, B. M. Simonetti, and A. Pierucci. 1985. Functional significance of renal prostacyclin and thromboxane $A_{2}$ production in patients with systemic lupus erythematosus. J. Clin. Invest. 76:1011-1018.

7. Remussi, G., L. Imberti, M. Rossini, C. Morelli, C. Carminati, G. M. Cattaneo, and T. Bertani. 1985. Increased glomerular thromboxane synthesis as a possible cause of proteinuria in experimental nephrosis. J. Clin. Invest. 75:94-101.

8. Coffman, T. M., W. E. Yarger, and P. E. Koltman. 1985. Functional role of thromboxane production by acutely rejecting renal allografts in rats. J. Clin. Invest. 75:1242-1248.

9. Rinder, C. A., P. V. Halushka, M. A. Sens, and D. W. Ploth. 1994. Thromboxane $A_{2}$ receptor blockade improves renal function and histopathology in the post-obstructive kidney. Kidney Int. 45:185-192.

10. Takahashi, K., F. Schreiner, K. Yamashita, B. W. Christman, I. Blair, and K. F. Badr. 1990. Predominant functional roles for thromboxane $A_{2}$ and prostaglandin $\mathrm{E}_{2}$ during late nephrotoxic serum glomerulonephritis in the rat. $J$. Clin. Invest. 85:1974-1982.

11. Spurney, R. F., P.-Y. Fan, P. Ruiz, F. Sanfillippo, D. S. Pisetsky, and T. M. Coffman. 1992. Thromboxane receptor blockade reduces renal injury in murine lupus nephritis. Kidney Int. 41:973-982.

12. Stahl, R. A. K., F. Thaiss, W. Schoeppe, U. Wenzel, and U. Helmchen. 1992. A rat model of progressive chronic glomerular sclerosis: role of thromboxane inhibition. J. Am. Soc. Nephrol. 2:1568-1577.

13. Perico, N., M. Rossini, O. Imberti, B. Malanchini, R. P. Cornejo, F. Gaspari, T. Bertani, and G. Remuzzi. 1992. Thromboxane receptor blockade attenuates chronic cyclosporine nephrotoxicity and improves survival in rats with renal isograft. J. Am. Soc. Nephrol. 2:1398-1404.

14. Hirata, M., Y. Hayashi, F. Ushikubi, Y. Yokota, R. Kageyama, S. Nakanishi, and S. Narumiya. 1991. Cloning and expression of a human thromboxane $A_{2}$ receptor. Nature (Lond.). 349:617-620.

15. Raychowdhury, M. K., M. Yukawa, L. J. Collins, S. H. McGrail, K. C. Kent, and J. A. Ware. 1994. Alternative splicing produces a divergent cytoplasmic tail in the human endothelial thromboxane $A_{2}$ receptor. J. Biol. Chem. 268:1925619261.

16. Namba, T., Y. Sugimoto, M. Hirata, Y. Hayashi, A. Honda, A. Watanabe, M. Negishi, A. Ichikawa, and S. Narumiya. 1992. Mouse thromboxane $A_{2}$ receptor: cDNA cloning, expression and Northern blot analysis. Biochem. Biophys. Res. Commun. 184:1197-1203.

17. Folger, W. H., P. V. Halushka, C. S. Wilcox, and N. J. Guzman. 1992. Characterization of rat glomerular thromboxane $A_{2}$ receptors: comparison to rat platelets. Eur. J. Pharmacol. 227:71-78.

18. Mené, P., M. S. Simmonson, and M. J. Dunn. 1992. Eicosanoids, mesangial contraction, and intracellular signal transduction. Tohoku J. Exp. Med. 166:5773.

19. Spurney, R. F., J. J. Onorato, F. Albers, and T. M. Coffman. 1993. Thromboxane binding and signal transduction in rat glomerular mesangial cells. Am. J. Physiol. 264:F292-F299.

20. Halushka, P. V., and R. M. Burch. 1984. Effects of arachidonic acid metabolites on ${ }^{45} \mathrm{Ca}$ fluxes and intracellular calcium in epithelial cells from the toad urinary bladder. In Prostaglandins and Membrane Ion Transport, P. Braquet, R. P. Garay, J. C. Frolich, and S. Nicosia, editors. Raven Press, Ltd., New York. 323-326.

21. Ishii, A., I. Miki, E. Ohshima, and H. Obase. 1990. Receptor profile of KW-3635: a potent, selective and orally active thromboxane $A_{2}$ receptor antagonist. Eur. J. Pharmacol. 183:1555.

22. Miki, I., N. Kishibayashi, H. Nonaka, E. Ohshima, H. Takami, H. Obase, and A. Ishii. 1992. Effects of KW-3635, a novel dibenzoxepin derivative of a selective thromboxane $A_{2}$ antagonist, on human, guinea pig and rat platelets. Jpn. J. Pharmacol. 59:357-364.

23. Murphy, T. J., R. W. Alexander, K. K. Griendling, M. S. Runge, and K. E. Bernstein. 1991. Isolation of a cDNA encoding the vascular type-1 angiotensin II receptor. Nature (Lond.). 351:233-236.

24. Abe, T., H. Sugihara, H. Nawa, R. Shigemoto, N. Mizuno, and S. Nakanishi. 1992. Molecular characterization of a novel metabotropic glutamate receptor mGluR5 coupled to inositol phosphate/ $\mathrm{Ca}^{2+}$ signal transduction. J. Biol. Chem. 267:13361-13368.

25. Scharschmidt, R. L., and M. J. Dunn. 1983. Prostaglandin synthesis by rat glomerular mesangial cells in culture: effects of angiotensin II and arginine vasopressin. J. Clin. Invest. 71:1756-1764.

26. Sato, M., K. Abe, K. Takeuchi, K. Mastui, M. Yasujima, S. Fang, M. Kanazawa, K. Yoshida, T. Kimura, and K. Yoshinaga. 1988. Cyclic GMP accumulation by atriopeptins in cultured rat renal and vascular smooth muscle cells. Tohoku J. Exp. Med. 154:399-411.

27. Takeuchi, K., R. W. Alexander, Y. Nakamura, T. Tsujino, and T. J. Murphy. 1993. Molecular structure and transcriptional function of the rat vascular AT1a receptor gene. Circ. Res. 73:612-621.

28. Takeuchi, K., T. Abe, N. Takahashi, and K. Abe. 1993. Molecular cloning and intrarenal localization of rat kidney prostaglandin $\mathrm{E}_{2}$ receptor $\mathrm{EP}_{3}$ subtype. Biochem. Biophys. Res. Commun. 194:885-891.

29. Takeuchi, K., K. Abe, M. Yasujima, S. Sato, K. Maeyama, T. Watanabe, M. Sato, H. Inaba, and K. Yoshinaga. 1992. Phosphoinositide hydrolysis and calcium mobilization induced by angiotensin II and vasopressin in vascular smooth muscle. Tohoku J. Exp. Med. 166:107-122.

0. Tsien, R. Y., T. Pozzan, and T. J. Rink. 1982. Calcium homeostasis in intact lymphocytes: cytoplasmic free calcium monitored with a new intracellularly trapped fluorescent indicator. J. Cell Biol. 94:325-334.

31. Grynkiewicz, G., M. Poenie, and R. Y. Tsien. 1985. A new generation of $\mathrm{Ca}^{2+}$ indicators with greatly improved fluorescence properties. J. Biol. Chem. 260:3440-3450.

32. Takahashi, N., Y. Kondo, O. Ito, Y. Igarashi, K. Omata, K. Abe. 1995. Vasopressin stimulates Cl-transport in ascending thin limb of Henle's loop in hamster. J. Clin. Invest. 95:1623-1627.

33. Takeuchi, K., N. Takahashi, T. Abe, and K. Abe. 1994. Two isoforms of the rat kidney $\mathrm{EP}_{3}$ receptor derived by alternative splicing: intrarenal expression co-localization. Biochem. Biophys. Res. Commun. 199:834-840.

34. Terada, Y., K. Tomita, H. Nonoguchi, and F. Marumo. 1993. PCR localization of angiotensin II receptor and angiotensinogen mRNAs in rat kidney. Kidney Int. 43:1251-1259.

35. Fort, P., L. Marty, M. Piechaczyk, S. E. Sabrouty, C. Dani, P. Jeanteur, and J. M. Blanchard. 1985. Various rat adult tissue express only one major mRNA species from the glyceraldehyde-3-phosphate-dehydrogenase multigene family. Nucleic Acids Res. 13:5463-5467.

36. Sambrook, J., E. F. Fritch, and T. Maniatis. 1989. Molecular Cloning, 2nd ed., Cold Spring Harbor Laboratory, Cold Spring Harbor, NY.

37. Kyte, J., and R. F. Doolittle. 1982. A simple method for displaying the hydropathic character of a protein. J. Mol. Biol. 157:105-132.

38. von Heijne, G. 1983. Patterns of amino acids near signal-sequence cleavage sites. Eur. J. Biochem. 133:17-21.

39. Funk, C. D., L. Furci, N. Moran, and G. A. Fitzgerald. 1993. Point mutation in the seventh hydrophobic domain of the human thromboxane $A_{2}$ receptor allows discrimination between agonist and antagonist binding sites. Mol. Pharmacol. 44:934-939.

40. Hubbard, S. C., and R. J. Ivatt. 1981. Synthesis and processing of asparagine-linked oligosaccharides. Annu. Rev. Biochem. 50:555-583.

41. Kemp, B., and R. Pearson. 1990. Protein kinase recognition sequence motifs. Trends Biochem. Sci. 15:342-346.

42. Dascal, N. 1987. The use of Xenopus oocytes for the study of ion channel. CRC Crit. Rev. Biochem. 22:317-387.

43. Suryanarayana, S., D. A. Daunt, M. von Zastrow, and B. K. Kobilka. 1991. A point mutation in the seventh hydrophobic domain of the $\alpha_{2}$ adrenergic receptor increases its affinity for a family of $\beta$ receptor antagonists. J. Biol. Chem. 266:15488-15492.

44. Savarese, T. M., and C. M. Fraser. 1992. In vitro mutagenesis and the search for structure-function relationships among $G$ protein-coupled receptors. Biochem. J. 283:1-19.

45. Spiegel, A. M., A. Shenker, and L. S. Weinstein. 1992. Receptor-effector coupling by $\mathrm{G}$ proteins: implications for normal and abnormal signal transduction. Endocr. Rev. 13:536-565.

46. Shenker, A., P. Goldsmith, C. G. Unson, and A. M. Spiegel. 1991. The $G$ protein coupled to the thromboxane $A_{2}$ receptor in human platelets is a member of the novel Gq family. J. Biol. Chem. 266:9309-9313.

47. Miki, I., H. Kase, and A. Ishii. 1992. Differences in activities of thromboxane $A_{2}$ receptor antagonists in smooth muscle cells. Eur. J. Pharmacol. 227:199204.

48. Paxton, W. G., M. Runge, C. Horaist, C. Cohen, R. W. Alexander, and K. E. Bernstein. 1993. Immunohistochemical localization of rat angiotensin II AT $_{1}$ receptor. Am. J. Physiol. 264:F989-F995.

49. Coppola, S., and E. Fromter. 1994. An electrophysiological study of angiotensin II regulation of $\mathrm{Na}-\mathrm{HCO}_{3}$ cotransport and $\mathrm{K}$ conductance in renal proxima tubules. I. Effect of picomolar concentrations. Pflügers Arch. 427:143-150.

50. Wolf, G., and E. G. Neilson. 1993. Angiotensin II as a renal growth factor. J. Am. Soc. Nephrol. 3:1531-1540.

51. Burch, R. M., D. R. Knapp, and P. V. Halushka. 1980. Vasopressinstimulated water flow is decreased by thromboxane synthesis inhibition and antagonism. Am. J. Physiol. 239:F160-F166. 